\title{
SUSTAINABLE OPERATIONS IN REVERSE SUPPLY CHAIN OF SHIPBUILDING BUSINESS: BENEFITS OF GREEN PRACTICES
}

\author{
Joshin John \\ Indian Institute of Management Lucknow, India \\ E-mail: joshinjohn7@gmail.com \\ Dr. Sushil Kumar, \\ Indian Institute of Management Lucknow, India \\ E-mail: sk@iiml.ac.in \\ Dr. K. N. Singh, \\ Indian Institute of Management Lucknow, India \\ E-mail:kns@iiml.ac.in \\ Dr. R. K. Srivastava, \\ Indian Institute of Management Lucknow, India \\ E-mail: rks@iiml.ac.in
}

Submission: $28 / 07 / 2013$ Accept: 14/08/2013

\section{ABSTRACT}

Sustainable operations have become extremely important for the survival of present day shipbuilding business wherein triple bottom-line criteria - profit, planet and people, needs to be satisfied. This paper discusses about recapturing value at the end-of-life of a ship and reintroducing it to the value chain through reverse supply chain channel, thereby reducing environmental impact and also benefitting humans and ecology. It also describes about the advantages of recycling ships vis-à-vis scrapping it in terms of environmental and human impact.

Keywords: Sustainable Operations, Reverse Supply Chain, Shipbreaking, Life Cycle Analysis. 
INDEPENDENT JOURNAL OF MANAGEMENT \& PRODUCTION (IJM\&P)

http://www.ijmp.jor.br

V. 4, n. 2, July - September 2013.

ISSN: 2236-269X

DOI: $10.14807 /$ ijmp.v4i2.110

\section{INTRODUCTION}

Shipbuilding, in the present day, is a multibillion dollar business with the major share of shipbuilding activity occurring in China, South Korea and Japan (Barry Rogliano Salles - Annual Review 2012). As the number of new ships introduced to the existing fleet of ships increase year-on-year, to meet the increasing demand of international trade, older ships are phased out from the fleet. The ships taken out of service are sent to the scrap yards for demolition and possible recovery of materials. However, lately there have been concerns on the environmental and human safety aspects, at places where demolition of ships take place. Almost 92 per cent of the ship scrapping in 2011 took place in developing Asian countries such as India, Bangladesh, China and Pakistan (UNCTAD, 2012).

Although there are economic implications of shipbreaking business as it provides jobs to thousands of people, there are legal, environmental and ecological safety issues as well. According to Basel Convention, prevention, minimization, recycling, recovery and disposal of hazardous and other wastes subject to the Basel Convention must be undertaken, taking into account social, technological and economic concerns. This is where sustainable operations have an important role to play. In order to balance the economic and environmental aspects of business, the supply chain may be extended to incorporate reverse logistics thereby recapturing value at the end of the value chain and reintroducing it back into supply chain. This will enable us achieve success in the form of the triple bottle line - profit, people, planet, all of which are vital in today's balance sheets, for businesses to survive (KLEINDORFER, et al. 2005). This paper also discusses on minimizing the carbon footprint in the business processes in the shipbuilding supply chain thereby making the processes more efficient and environment friendly.

\section{LITERATURE REVIEW}

There are mainly four areas where the extant literature has been studied. They are: reverse and closed loop supply chains, ship-breaking business, sustainable operations and ship recycling process. A brief of the literature that has been reviewed is elaborated, as follows: 
INDEPENDENT JOURNAL OF MANAGEMENT \& PRODUCTION (IJM\&P)

http://www.ijmp.jor.br

V. 4, n. 2, July - September 2013.

ISSN: 2236-269X

DOI: 10.14807/ijmp.v4i2.110

\subsection{Reverse and closed loop supply chains}

Strategic issues in product recovery management (PRM) have been studied (THIERRY et al., 1995), and the information required for making accurate analysis on PRM has been enlisted as: composition of manufactured product, magnitude and uncertainty of return flows, markets for reprocessed products and materials, actual product recovery and waste management operations, product recovery options, repair, refurbishing, remanufacturing, cannibalization, and recycling. Quantitative models for reverse logistics have been developed (FLEISCHMANN, et al., 1997) including MRP system for product recovery. Product returns for remanufacturing may be managed by a mix of activities termed as product acquisition management (GUIDE, WASSENHOVE, 2000) which includes value creation, profit maximization by product returns management, operations streamlining and creating new markets for reused goods and products. The options for collecting used products for remanufacturing in a closed loop supply chain has been analyzed (SAVASKAN et al., 2004). Among three options dealt within the study i.e. - direct collection from customer, collection by retailer and collection by third party, it has been concluded that maximum supply chain profits (as same as centrally coordinated supply chain) are attained when the retailer collects the used product. The case of competing retailers in the reverse channel design has been studied (SAVASKAN, WASSENHOVE, 2006) wherein there is interaction between manufacturer's reverse channel choice to collect used goods and the forward channel pricing decision. When the buy-back payments are transferred to the retailers for postconsumer goods, as against direct collection, a wholesale pricing is achieved that can be used to price discriminate between retailers of different profitability.

\subsection{Shipbreaking business}

Much has been discussed in literature about shipbreaking in recent times due to the controversies regarding dumping of toxic waste materials associated with the shipbreaking process. This has renewed interests in developing methods by which scrapping of ships may take place without adversely affecting the environment. Reddy et al. (2003) have discussed about the quantification and classification of ship scrapping waste at Alang-Sosiya (India), one of the biggest ship-breaking yards in the world. This industry generates a huge quantity of solid waste in the form of broken wood, rubber, insulation materials, paper, metals, glass and ceramics, 
INDEPENDENT JOURNAL OF MANAGEMENT \& PRODUCTION (IJM\&P)

http://www.ijmp.jor.br

V. 4, n. 2, July - September 2013.

ISSN: 2236-269X

DOI: 10.14807/ijmp.v4i2.110

plastics, leather, textiles, food waste, chemicals, paints, thermocol, sponge, ash, oil mixed sponges, miscellaneous combustible and non-combustible substances. A sampling experiment revealed that 96.71 metric tons of wastes per day are deposited on the shore due to the scrapping activity (REDDY, et al., 2003).

Hossain and Islam (2006) conducted a study on the ship breaking activities and its impact on the coastal zone of Chittagong (Bangladesh). They have come up with a fourteen point recommendation for incorporating sustainable practices in ship breaking industry. European Commission Directorate General (July 2007) in its report has prescribed the guidelines for ship dismantling and pre-cleaning of ships, including exploring different options for developing strategies for ship dismantling in European Union. A statistical overview of ship recycling was carried out in order to quantify some aspects of recycling such as size of operating fleet, lightship, age of ship etc. (MIKELIS, 2007).

The work provided some interesting insights such as: there is a direct correlation between the freight markets and recycling prices. Price differentials that exist are not only due to shipping market but also due to differences in labor and environmental costs in recycling at different locations, and due to the internal ship steel demand in different economies. The activities at Alang ship-breaking yard, including conditions of workers, impact of shipbreaking on ecology, and recent controversies on asbestos dumping has been treated in detail (THOMAS, 2007). The case of scrapping of asbestos laden Blue Lady (cruise liner) at Alang, and the legal, environmental and human hazard related problems associated with it has been elaborated (PELSY, 2008).

Sonak et al. (2008) discusses the case of French aircraft carrier "Le Clemenceau", which was sent to Alang, India, for disposal. They further assessed the implications of shipping hazardous waste to developing countries and emphasized the need for promoting research to plug the gaps and for implementing stringent measures to check the trade of environmental pollutants. In order to ascertain quantitatively, a methodology to model the environmental impacts of ship dismantling has been suggested (CARVALHO, et al., 2009). They have also elaborated on the impact on the ecology with respect to the type of ship that is being dismantled. 


\subsection{Sustainable operations}

The idea of sustainable operations has gained much ground especially in the last decade, due to concerns about the ecological and human impact of day-to-day operations. The evolution of sustainable operations management has been thoroughly elaborated (KLEINDORFER, et al., 2005) detailing the three major areas of integration of sustainable operations i.e. green product \& process development, lean \& green operations management and remanufacturing \& closed-loop supply chains. Demaria (2010) explained about the ecological distribution conflict emanating out of dumping toxic wastes associated with ship breaking, at the cost of environment, local workers, farmers and fishers.

In his doctoral dissertation, Sivaprasad (2010) has elaborated on formulating a set of best practices for sustainable development in ship-breaking industry and implementing the $4 \mathrm{E}$ principles i.e. eco- friendliness, engineering efficiency, energy conservation and ergonomics in core operations. Technologies for reduced environmental impact from ships - ship building, maintenance and dismantling aspects have been discussed (Hayman, et al. 2010) at length.

\subsection{Ship recycling process}

Statistical data regarding ship recycling has been collated and discussed in detail (MIKELIS, 2008). Chang et al. (2009) has elaborated on the historical background, structure and enforcement of the Hong Kong International Convention on safe and environmentally sound recycling of ships. The polycyclic aromatic and aliphatic hydrocarbons pollution at the coast of Aliga (Turkey) ship recycling zone has been studied in detail by Neser et al. (2012). In this study, sediments were investigated to perform an environmental risk assessment. The results suggested that the sediments were likely to be contaminated. The pollution was due to shipbreaking industry and the petrochemical complex.

Dimakopoulos (2005) described about International Maritime Organization's (IMO) role in ship recycling activities. The formation of guidelines by special working group formed by Marine and Environmental Pollution Committee (MEPC) of IMO and International Labour Organization (ILO) has been discussed. He further elaborated on how recycling contributes to sustainable development and why IMO encourages and promotes ship recycling in compliance with the international standards of safety, 
INDEPENDENT JOURNAL OF MANAGEMENT \& PRODUCTION (IJM\&P)

http://www.ijmp.jor.br

V. 4, n. 2, July - September 2013.

ISSN: 2236-269X

DOI: 10.14807/ijmp.v4i2.110

health and environment. Hossain et al. (2010) has discussed on the recent status of ship recycling industry in Bangladesh. They have further elaborated on the social and environmental impacts of ship recycling, its positive economical contribution and also its negative effects like lack of occupational health and safety standards. It has been further analyzed whether it is better in an overall sense for Bangladesh to support this business on its own soil. Some viable recommendations have been made in the conclusion.

\section{REVERSE SUPPLY CHAIN MODEL IN SHIPBUILDING BUSINESS}

In the classical business supply chain of manufacturing industries, the finished product passes on from manufacturer to wholesaler, then from the wholesaler to retailer, then from the retailer to the customer who is the end-user of the product. After the service life of the product, the customer 'throws away' or disposes the product. This was the case till a few decades ago. However, in recent times, the producer or manufacturer of the product has been trying to retrieve the product from the customer after its use. This is done by providing incentives to the customer, for example, by buying back the product (of course, at a reduced price) at collection points (for instance, authorized retailers, $3^{\text {rd }}$ party collectors etc.) near the location of customers.

Collection of disposed products and remanufacturing helps the manufacturer to achieve the 3 Ps. Increase in 'profits' due to reduction in cost of manufacturing from raw materials, as disposed products can be collected and refurbished, recycled or remanufactured. 'Planet' friendly - lesser damage to the environment as disposed products are not released into the environment, but rather collected back. 'People' friendly - better health for humans, as they are saved from toxicity that emanate from products that are dumped in the environment. An illustration of the reverse supply chain is shown in Figure 1.

Similarly, for shipbuilding business as well, there is an extension of the classical supply chain, to make it a closed loop supply chain. The difference of shipbuilding closed loop supply chain from that of normal products such as FMCG goods or automobiles is that the collection point of decommissioned ships (ships out of service) is clustered. 


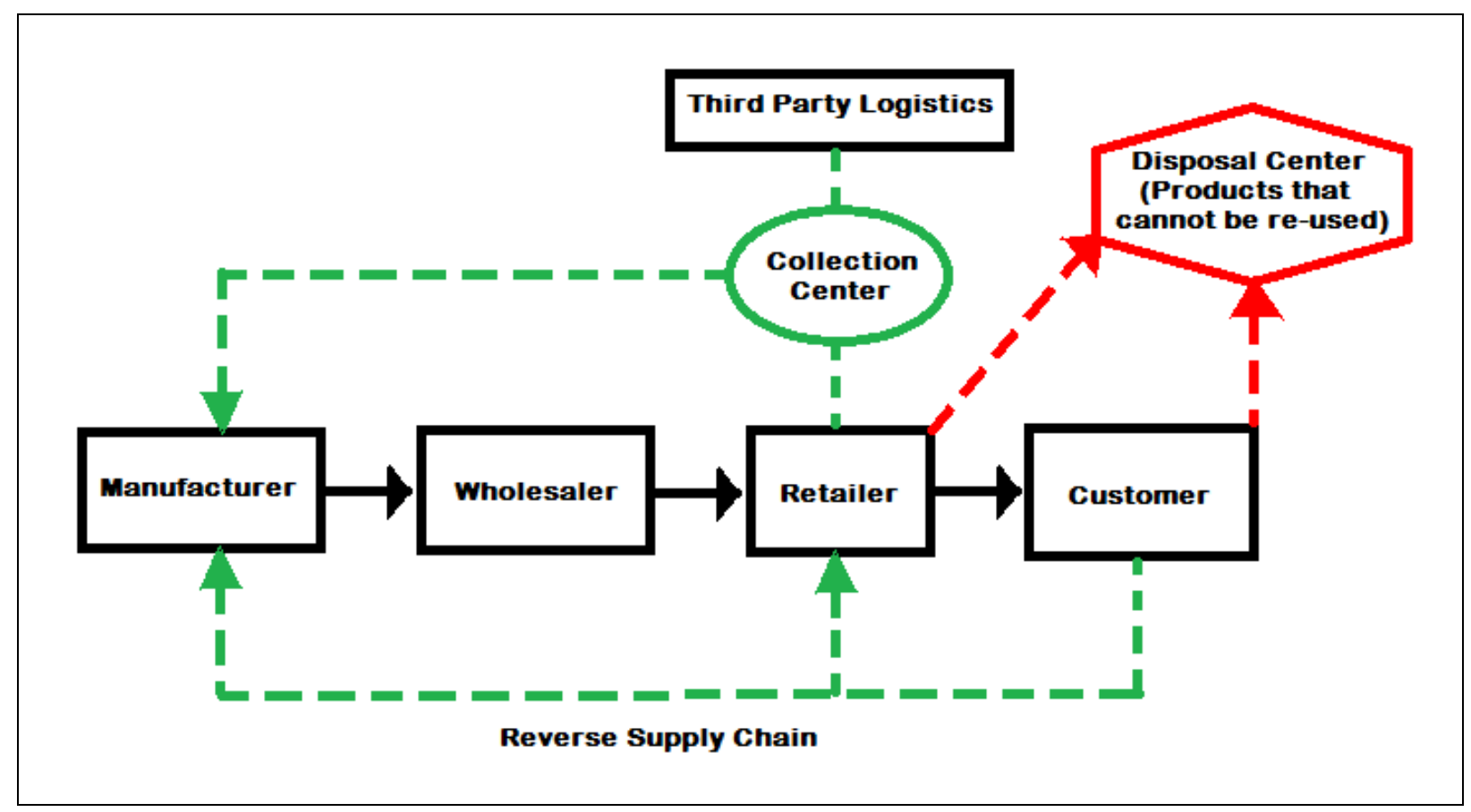

Figure 1 - Reverse Supply Chain

This is an advantage as the collection effort required is lesser than for other products. Over the last decade, over $80 \%$ of the world ship breaking took place in two ship breaking yards, one at Alang (India) and two at Chittagong (Bangladesh). These shipbreaking yards are a dominant source of cheap ship steel which constitutes almost 95 per cent of the ship (ABDI, 2003).

The 6,000 metric tons of steel that come out of Alang every day, on average, account for about 15 per cent of India's total steel output. It is not just steel that come out of these mammoth shipbreaking yards. A plethora of machinery and outfit components are also sold cheap at second hand rates. These include air compressors, chilling units, lathe machines, drilling machines, welding generators, oil purifiers, oil pumps, water pumps, heat exchangers, condensers, diesel generators, alternators, marine engines, incinerators, turbochargers, and many more equipment. Various outfit items and household equipment such as ladders, kitchen appliances, kitchen machinery, office and home furniture, handrails, fittings, mirrors, cupboards and sideboards, crockery and cutlery, flower pots and holders, used cables, steel pipes, nuts and bolts, screws, electric motors, bulbs and light fittings, wood, partition sheets etc. are also sold at considerable discount rates.

The sustainability part of the business chain comes into play with the accrual of profit that emanates out of shortening of the supply chain. The steel procured for 
ship construction previously was imported predominantly from abroad, which is now available as recycled steel at reduced prices. The lead time for procurement and transportation costs also reduce by purchasing from steel from nearby mills that produce recycled steel. This is as shown in Figure 2.

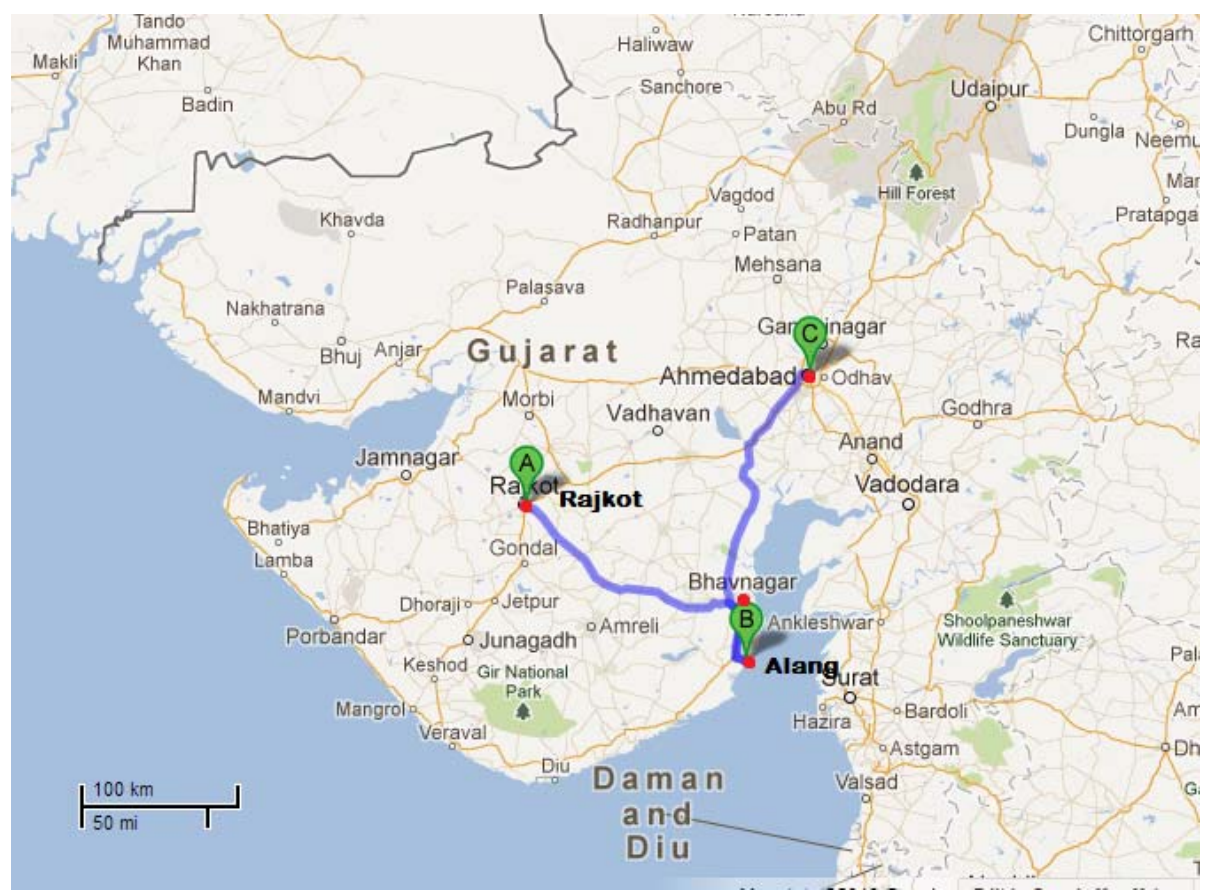

Figure 2 - Reverse Supply Chain in Gujarat

The distance to be covered for transporting steel from East Asian countries like Japan and South Korea to Gujarat in India is about 20,000 km. This gets reduced to less than $250 \mathrm{~km}$ when scrap steel from Alang is sent for recycling at mills in Gujarat at nearby districts of Rajkot and Ahmedabad. The re-rolled steel is sent as raw material to shipyards in Bhavnagar and Hazira which are at close proximity, as can be seen in the figure.

Apart from this, use of recycled steel reduces the usage of virgin natural resources such as iron ore. The installation of steel recycling mills also provides employment opportunities to thousands of workers in the region. However, there are concerns about the environmental and human hazard problems associated with the shipbreaking industry. Part of the extra profits accrued from the closed loop supply chain can be allocated to resolve this problem. This is treated in detail in the next section. 


\subsection{Environment and human friendly ship-recycling}

Much of the environmental damage occurs due to breaking of the ship by the beaching method, which is practiced in the Indian subcontinent, without pre-cleaning of ships. The old ships contain toxic substances like mercury, asbestos, oil sludge, bilge, ballast water, zinc and other heavy metals which if released freely poses a danger to the environment, as it adversely affects agricultural produce, fishing catchment, human safety etc. (DEMARIA, 2010).

Thus, it is imperative for the ship-owners to decontaminate the ship, and remove all the hazardous wastes prior to export to its graveyard destination. The other alternative would be to remove the environmentally toxic materials once the ship has arrived at the site of shipbreaking. This option is recommended by International Maritime Organization (IMO).

Till now, the ship-owners have been reluctant to bear the extra costs of precleaning the olds ships, which the BASEL convention requires them to do so for disposing ships out of service. However, with the changing equation, instilled by sustainable operations practices, it becomes possible for ship owners to scrap ships without spending too much money or damaging the environment. The classical equation for ship scrapping without sustainable operations practices is as shown below:

$$
\sum X_{i}=P_{i}+W_{i}+A_{i}+E_{i}+H_{i}
$$

Where,

$$
\begin{aligned}
& \sum X_{i}=\text { Total cost for scrapping } \mathrm{i}^{\text {th }} \text { ship } \\
& P_{i}=\text { Pre-cleaning cost before scrapping } \mathrm{i}^{\text {th }} \text { ship } \\
& W_{i}=\text { Labour and equipment cost for scrapping } \mathrm{i}^{\text {th }} \text { ship } \\
& A_{i}=\text { Administration and licensing cost for scrapping } \mathrm{i}^{\text {th }} \text { ship } \\
& E_{i}=\text { Environmental cost (damage to environment) due to scrapping } \mathrm{i}^{\text {th }} \text { ship } \\
& H_{i}=\text { Human hazard cost related to scrapping } \mathrm{i}^{\text {th }} \text { ship }
\end{aligned}
$$

As the $W_{i}$ and $A_{i}$ components cannot be done away with, as it is integral to the part of ship-breaking, most players in the business try to do away with the $P_{i}$ component (pre-cleaning cost). This is at the expense of environmental and human 
hazard related cost $\left(E_{i}+H_{i}\right)$. The inclusion of sustainable operations practices and usage of recycled steel for ship-building purposes in yards located in close proximity, tweaks the equation in the following beneficial form.

$$
\sum X_{i}=P_{i}+W_{i}+A_{i}+E_{i}+H_{i}-M_{i}-T_{i}
$$

Where the new terms are,

$M_{i}=$ Price of steel sold for recycling from $\mathrm{i}^{\text {th }}$ ship

$T_{i}=$ Reduction in transportation cost due to steel procured from scrapping of $\mathrm{i}^{\text {th }}$ ship

The introduction of the new terms $\mathrm{M}_{\mathrm{i}}$ and $\mathrm{T}_{\mathrm{i}}$, partly bears to provide for the precleaning costs of ships to be scrapped. The pre-cleaning and effective decontamination of ships will decrease the environmental and human hazard related costs associated with shipbreaking. Sustainable operations in shipbreaking also involve reducing the carbon footprint associated with the shipbuilding supply-chain. The carbon dioxide emissions in freight transport in grams carbon per ton freight carried per kilometer by different modes of transport are as shown in Figure 3.

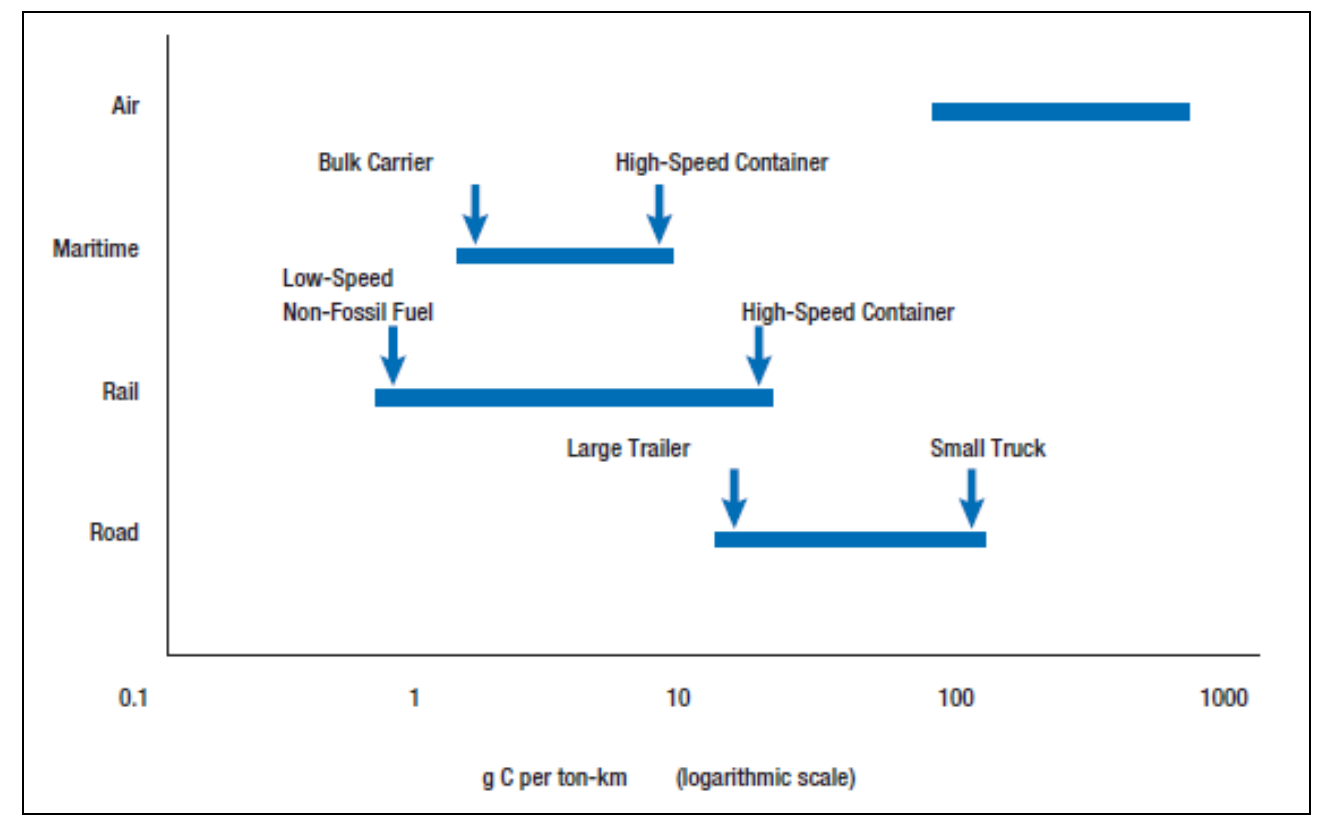

Figure 3 - Comparison of $\mathrm{CO}_{2}$ emissions in freight transport by mode of transport Source: UNCTAD, 2012

Needless to say that there is significant reduction in carbon dioxide emission by local sourcing of steel than importing from abroad. For instance, procuring steel from a recycling mill located $250 \mathrm{~km}$ from the yard instead of a steel manufacturer 
(located in East Asia) 20,000 km away (even by a bulk carrier which has the lowest carbon footprint by maritime route) saves $\mathrm{CO}_{2}$ emissions of the order of $20 \mathrm{~kg} \mathrm{CO}$ per ton of freight carried. To put this in real life perspective, for building an average general cargo ship of 20,000 Lightweight Tons, the savings accrued due to procurement from local recycling yard is of the order of 400 Tons of $\mathrm{CO}_{2}$ emission.

Therefore, the ship-owners have an incentive to trade carbon credits to the local shipbuilders as a motivation to buy from the local steel recycling mills. Similar to steel sourcing, machinery and outfit components may also be sourced locally if refurbishment of old equipment to 'new equipment quality' is viable and technologically feasible.

\section{BENEFITS OF GREEN PRACTICES}

In this section we shall deal with the advantages of recycling a ship vis-à-vis scrapping a ship in a more analytic manner using a tool. This analysis is called lifecycle-assessment or cradle-to-grave analysis. The tool we are using is "OpenLCA", an open source software used for cradle-to-grave analysis. Note that in this context we are doing a relative analysis of the benefits of recycling a ship with respect to scrapping it, not an absolute one. Nevertheless, the results we obtain are valuable.

\subsection{Methodology of Life Cycle Assessment}

Firstly, in order to do the life cycle assessment, we have to define the boundary of a system and the materials that go into and out of it, and the path they follow. In our case, the ship we take into consideration is a 'RoRo-LoLo SemiSubmersible Heavy Lift Container Carrier Vessel" that is ready for disassembly. We collate all the material part and residual inventory of the vessel from authentic sources. Then we define various flows and processes through which the materials go through in each scenario, be it ship scrapping or ship recycling. This is done in the input/output columns where in details such as amount of steel sections, distance travelled, amount of heavy fuel, plastic wastes, landfill details, amount of incinerated wastes etc. are fed into the software.

The impact assessment method employed is CML 2001 of Center of Environmental Science of Leiden University. Two hypothetical product systems namely, 'recycling' and 'scrapping' are compiled. In the project tab, comparison of the product systems are done by CML 2001 method, based on various parameters. A 
maximum of about 50 comparisons can be done for different parameters in CML 2001. We perform about 14 major comparisons.

\subsection{Results}

The results of the important comparisons of the "recycling product system" versus "scrapping product system" are shown as below.

Acidification potential - generic

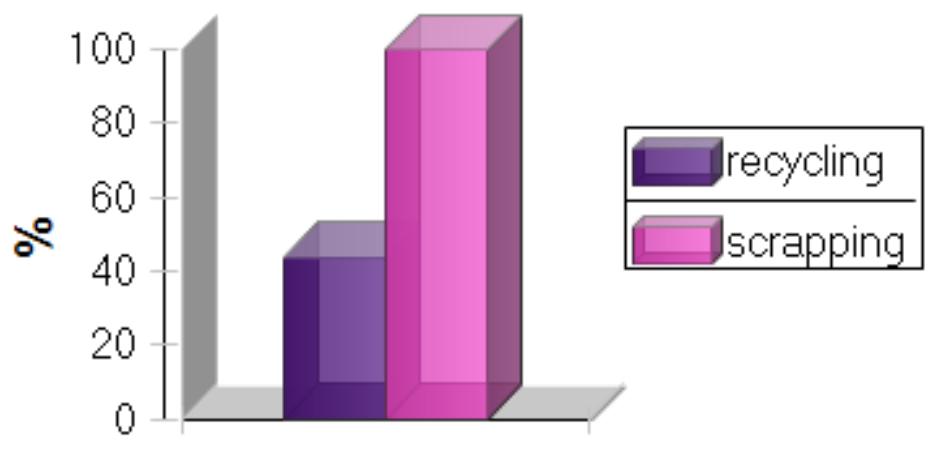

Acidification potential is the result of aggregating acid air emissions, expressed in $\mathrm{SO}_{2}$ equivalents. The acidification potential is an important environmental indicator.

Figure 4 - Acidification Potential: Recycling vs. Scrapping

Climate change - GWP 500a

Climate change refers to any significant change in the measures of climate lasting for an extended period of time. In other words, climate change includes major changes in temperature,

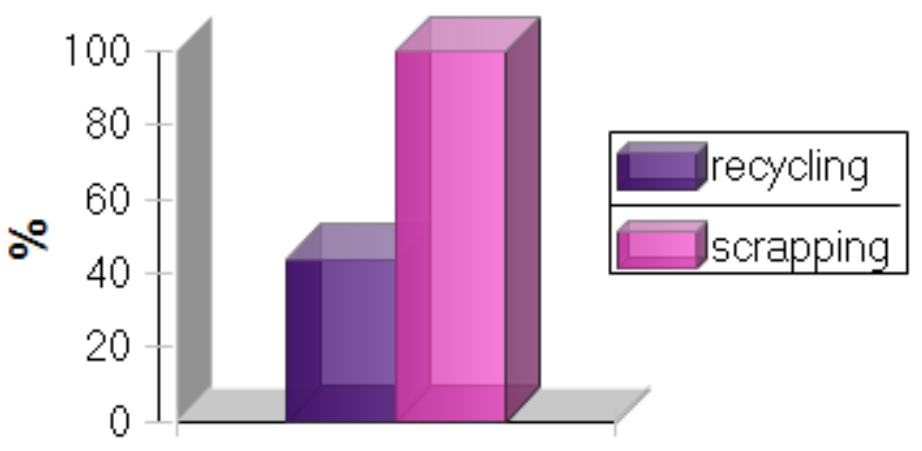
precipitation, or wind patterns, Figure 5 - Climate Change: Recycling vs. Scrapping among other effects, that occur over several decades or longer. 


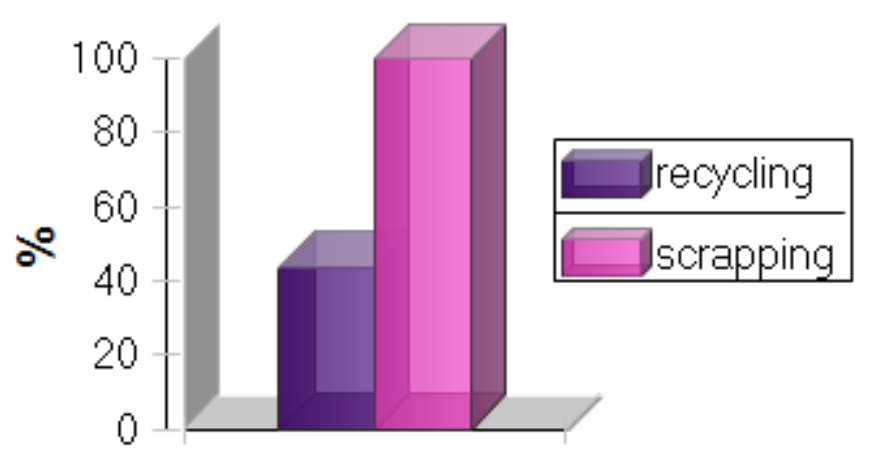

Eutrophication Potential is defined as the potential of nutrients to cause overfertilization of water and soil which in turn can result in increased growth of biomass.

Figure 6 - Eutrophication Potential: Recycling vs. Scrapping

Freshwater aquatic eco-toxicity - FAETP 500a

Freshwater Aquatic Eco-toxicity refers to the impact on fresh water ecosystems, as a result of emission of toxic substances to air, water and soil. Eco-toxicity Potential (FAETP) is calculated with USES-LCA, describing fate, exposure and effects of toxic substances. Characterization factors are expressed as 1,4-dichlorobenzene

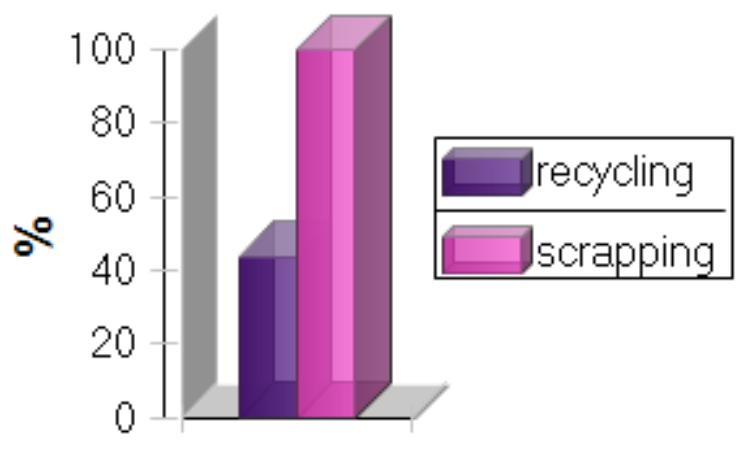

Figure 7 - FAETP: Recycling vs. Scrapping equivalents $/ \mathrm{kg}$ emission. The indicator applies at global/continental/ regional and local scale. 


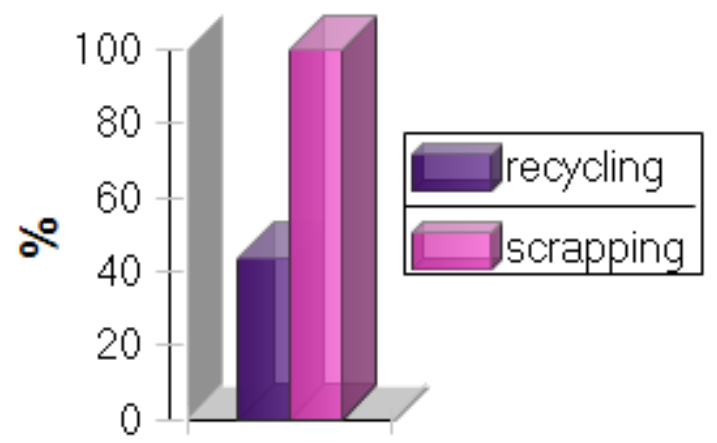

Freshwater sediment eco-toxicity is the impact on the sediments of freshwater or increase in the amount of toxic substances such as heavy metals (cadmium, for example) over a period of time.

Figure 8 - FSETP: Recycling vs. Scrapping

Human toxicity - HTP 500a

Human Toxicity is the degree to which

a chemical substance elicits a deleterious or adverse effect upon the biological system of human exposed to the substance over a designated time period. The human toxicity potential (HTP) reflects the potential harm of a unit of chemical released into the environment. It is based on both the inherent toxicity of a compound and its potential dose. It is used to weigh

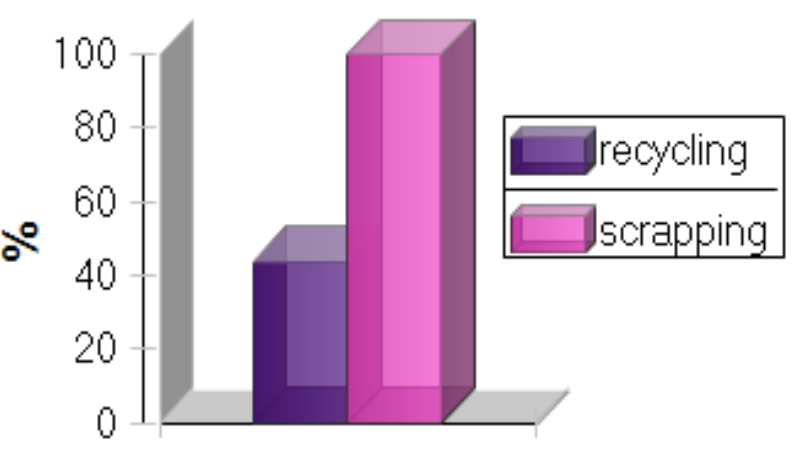

Figure 9 - HTP: Recycling vs. Scrapping emissions inventoried as part of a lifecycle assessment or in the toxic release inventory and to aggregate emissions in terms of a reference compound. 
lonizing radiation

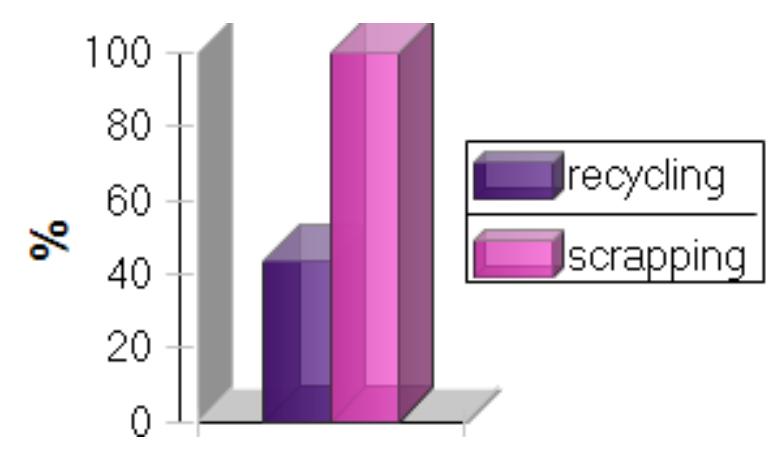

Figure 10 - lonizing Radiation: Recycling vs. Scrapping
Ionizing radiation is radiation with enough energy so that during an interaction with an atom, it can remove tightly bound electrons from the orbit of an atom, causing the atom to become charged or ionized. Longer wave lengths, lower frequency waves (heat and radio) have lesser energy than shorter wave length than higher frequency waves (X-rays and gamma rays). Only the high frequency portion of the electromagnetic spectrum which includes $\mathrm{X}$-rays and gamma rays is ionizing.

\section{Land-use - competition}

Land use competition refers to the conflict over multiple forms of use for land resources especially over agricultural use. This graph shows the amount of land lost from agricultural usage for recycling and scrapping of ships respectively.

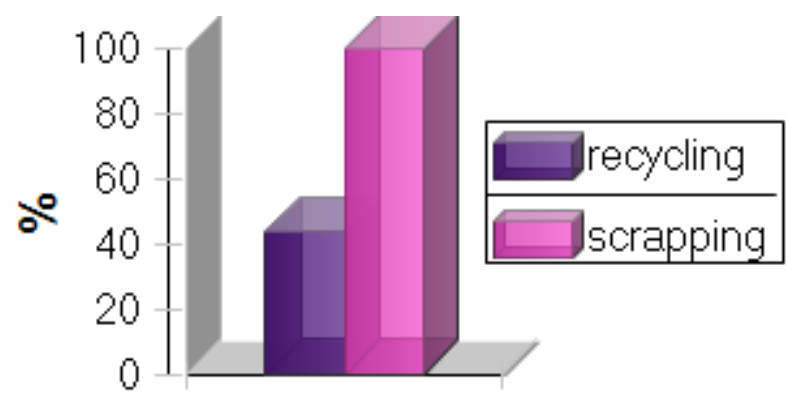

Figure 11 - Land use competition: Recycling vs. Scrapping 


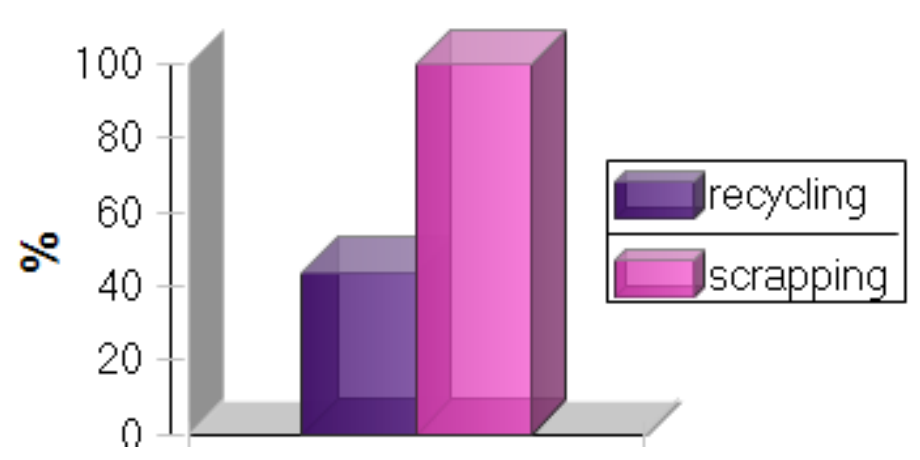

Figure 12 - Marine Aquatic Eco-toxicity: Recycling vs. Scrapping
Marine aquatic ecotoxicology refers to the impact of toxic substances emitted to marine aquatic ecosystems. The characterization factor is the potential of marine aquatic toxicity of each substance emitted to the air, water or/and soil. The unit of this factor is $\mathrm{kg}$ of 1,4- DB equivalents per $\mathrm{kg}$ of emission.

Marine sediment eco-toxicity - MSETP 500a

Marine sediments eco-toxicity refers to the accumulation of a variety of contaminants that demonstrate toxicity. Toxicity identification evaluation (TIE) methods provide tools for identifying the toxic chemicals causing sediment toxicity like arsenic and chromium.

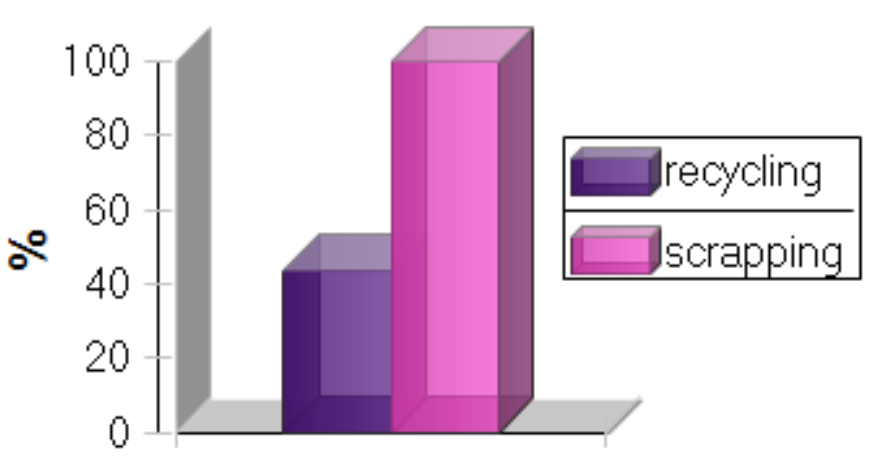

Figure 13 - MSETP: Recycling vs. Scrapping 
Photochemical oxidation (summer smog) - EBIR

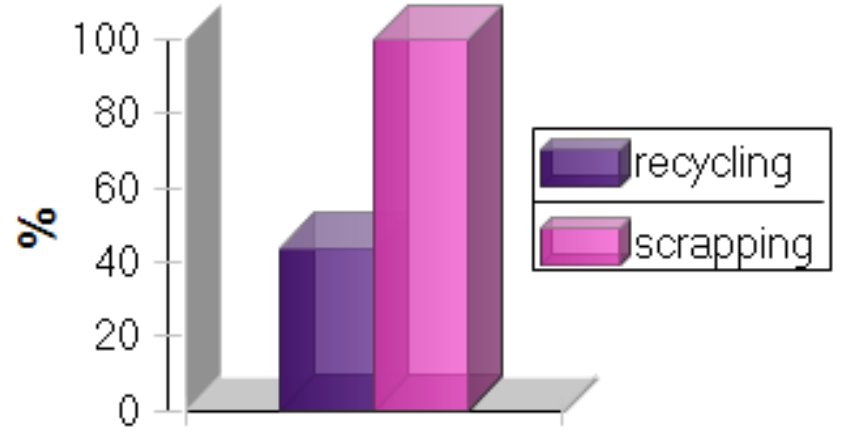

Figure 14 - Summer Smog:

Recycling vs. Scrapping
Oxidation occurs when a substance poses an electron and combines with another substance. In some cases this reaction is initiated by having the atoms excited by a wave length of light such as the Ultraviolet. The presence of a catalytic surface like Ti-O may assist the process. Photochemical oxidation is therefore the reaction of a chemical change in a substance which causes it to lose electrons which is initiated by light.

A common example is photochemical smog which is caused by hydrocarbons and $\mathrm{NO}_{\mathrm{x}}$ reacting under the influence of UV light.

Resources - depletion of abiotic resources

This graph denotes the depletion of abiotic substances (any fundamental chemical element or compound in the environment like hydrogen, oxygen, carbon etc.) due to recycling and scrapping of ship Figure 15 -Depletion of Abiotic Substances: Recycling respectively.

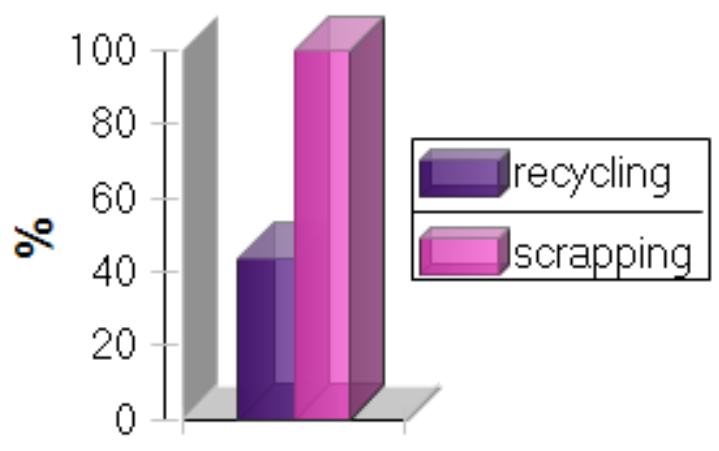

vs. Scrapping 


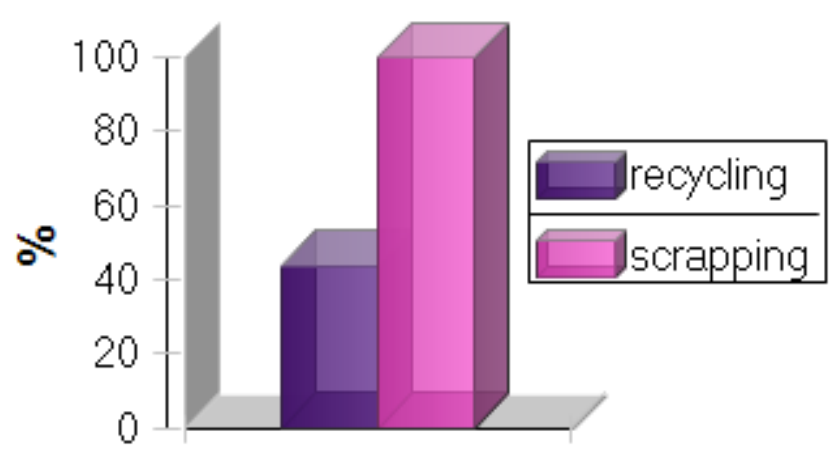

Figure 16 - ODP - Recycling vs. Scrapping
The growing emissions of synthetic chlorofluorocarbon molecules cause a significant diminution in the ozone content of the stratosphere, with the result that more solar ultraviolet-B radiation (290-320 $\mathrm{nm}$ wavelengths) reaches the surface. This ozone loss occurs in the temperate zone latitudes in all seasons, and especially drastically since the early 1980 s in the south polar springtimecausing the 'Antarctic ozone hole'.

Ozone depletion are primarily based on atomic $\mathrm{Cl}$ and $\mathrm{Cl}-\mathrm{O}$, the product of its reaction with ozone. The graph shows the stratospheric ozone depletion due to recycling and scrapping of ships respectively.

Terrestrial eco-toxicity - TAETP 500a

Terrestrial eco-toxicity has been defined as a parametric index in the subfield of ecotoxicology which uses tests to study, evaluate and quantify the effects of toxic substances on the diversity and function in soil-based plants and animals. Apart from measuring the relevant parameters and meeting environmental requirements, an effective toxicity test should be quick, simple, and replicable. A standard test

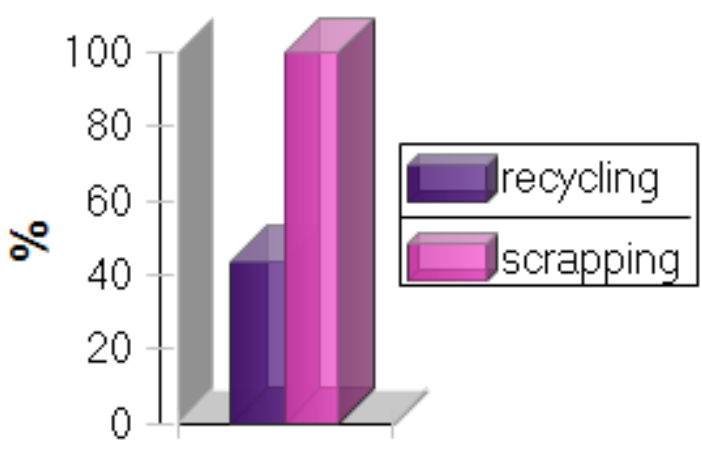

Figure 17 - TAETP: Recycling vs. Scrapping 
variation in environmental conditions such

as $\mathrm{pH}$, solubility, exposure time, antagonism, and synergy.

\section{CONCLUSION}

The reverse supply chain in shipbreaking helps the shipping industry gain financial value out of zero-value vessels. It also enables the ship owner do away with the operational burden of maintaining vessel which has higher operating costs than its revenue. The reverse supply chain of large Built-to-order (BTO) products, like ships, provide huge amount of re-rollable steel without exploiting natural resources. The western geography of India does not have steel producing units. The shipbreaking industry provides balance to the steel sector by providing used steel to rerolling mills in Rajkot, Kutch, Hariza and Surat (Gujarat).

Therefore, the ship recycling industry saves a lot of time and logistics cost for the steel sector industries. In addition to this, the reverse supply chain also gives a heads up to sustainable business practices as it reduces the $\mathrm{CO}_{2}$ emission and reduces damage to the environment. A comparison based on CML 2001 life cycle assessment of various variables such as acidification potential, climate change, eutrophication potential, freshwater aquatic eco-toxicity, freshwater sediment ecotoxicity, human toxicity, ionizing radiation, land-use competition, marine aquatic ecotoxicity, marine sediment eco-toxicity, chemical oxidation, depletion of abiotic resources, stratospheric ozone depletion, terrestrial eco-toxicity revealed that recycling of ships offers much greater advantage than scrapping of ships, at an environmental as well as human safety level.

\section{REFERENCES}

ABDI R. (2003) India's Ship-Scrapping Industry: Monument to the Abuse of Human Labour and the Environment. IIAS Newsletter. v. 32, n. 46.

BARRY ROGLIANO SALLES. (2012) Annual Review. v. 8, n. 22. Available online at http://www.brs-paris.com/index.php?page=annualreview (Accessed date $5^{\text {th }}$ February 2013).

CARVALHO, I. S.; ANTÃO, P.; SOARES, C. G. (2009) Modelling of environmental impacts of ship dismantling. Marine Technology, Technical University of Lisbon, Portugal. ISBN 978-0-415-54934-9. p. 533-542.

CHANG Y, C.; WANG, N.; DURAK, O. S. (2010) Ship Recycling and Marine Pollution. Marine Pollution Bulletin. v. 60, n. 9, p. 1390-1396. 
INDEPENDENT JOURNAL OF MANAGEMENT \& PRODUCTION (IJM\&P)

http://www.ijmp.jor.br

V. 4, n. 2, July - September 2013.

ISSN: 2236-269X

DOI: 10.14807/ijmp.v4i2.110

DEMARIA, F. (2010) Shipbreaking at Alang-Sosiya (India): An ecological distribution conflict. Ecological Economics. v. 70, n. 2, p. 250-260.

DIMAKOPOULOS, S. (2005) The IMO's work on ship recycling. IMO News. v. 2, p. 18-21.

EUROPEAN COMMISSION DIRECTORATE GENERAL ENVIRONMENT. (2007) Ship dismantling and pre-cleaning of ships - Final Report.

FLEISCHMANN M., J. M.; BLOEMHOF-RUWAARD, R.; DEKKER,E.; VAN DER LAAN, J. A.; VAN NUNEN, E. E.; VAN WASSENHOVE, L. N. (1997) Quantitative models for reverse logistics: A review. European Journal of Operational Research. v. 103, n. 1, p. 1-17.

GUIDE V. D. R.; WASSENHOVE, L. N. V. (2001) Managing Product Returns for Remanufacturing. Production and Operations Management. v. 10, n. 2, p. $142-$ 155.

HAYMAN B.; DOGLIANI M.; KVALE I.; FET A. M. (2000) Technologies for reduced environmental impact from ships - Ship building, maintenance and dismantling aspects. Available online at http://www.iot.ntnu.no/users/fet/konferanser/2000treship-newcastle.pdf (Accessed date $6^{\text {th }}$ February 2013).

HOSSAIN K. A.; IQBAL K. S.; ZAKARIA N. M. G. (2010) Ship Recycling Prospects in Bangladesh. Proceedings of MARTEC 2010. The International Conference on Marine Technology. BUET, Dhaka, Bangladesh. P. 297-302.

HOSSAIN M. M.; ISLAM, M. M. 2006. Ship Breaking Activities and its Impact on the Coastal Zone of Chittagong, Bangladesh : Towards Sustainable Management. Young Power in Social Action (YPSA), Chittagong, Bangladesh.

KLEINDORFER P. R.; SINGHAL K.; WASSENHOVE, L. N. V. (2005) Sustainable Operations Management. Production and Operations Management. v. 14, n. 4, p. 482-492.

MIKELIS, N. E. (2007) A statistical overview of ship recycling. International Symposium on Maritime Safety, Security \& Environmental Protection, Athens

MIKELIS, N. E. (2008) A statistical overview of ship recycling. WMU Journal of Maritime Affairs. v. 7, n. 1, p. 227-239.

NEZER, G.; KONTAS, A.; UNSALA, D.; ALTAY, O.; DARILMAZ, E.; ULUTARHAN, E.; KUCUKSEZGIN, F.; TEKOGUL, N.; YERCAN, F. (2012) Polycyclic aromatic and aliphatic hydrocarbons pollution at the coast of Aliağa (Turkey) ship recycling zone. Marine Pollution Bulletin. v. 64, n. 5, p. 1055-1059.

PELSY, F. (2008) The blue lady case and the international issue of ship dismantling. Law Environment and Development Journal, v. 4, n. 2, p. 135-148.

REDDY, M. S.; BASHA, S.; KUMAR, V. G. S.; JOSHI, H. V.; GHOSH, P. K. (2003) Quantification and classification of ship scraping waste at Alang-Sosiya, India. Marine pollution bulletin. v. 46, n. 12, p. 1609-1614.

SAVASKAN, R. C.; BHATTACHARYA, S.; VAN WASSENHOVE, L. N. (2004) Closed-Loop Supply Chain Models with Product Remanufacturing. Management Science, v. 50, n. 2, p. 239-252.

SAVASKAN, R. C.; VAN WASSENHOVE, L. N. (2006). Reverse Channel Design: The Case of Competing Retailers. Management Science. v. 52, n. 1, p. 1-14. 
SIVAPRASAD, K. 2010. Development of best practices for ship recycling processes. Doctoral Thesis. Cochin University of Science and Technology, Cochin.

SONAK, S.; SONAK, M.; GIRIYAN, A. (2008) Shipping hazardous waste: implications for economically developing countries. International Environmental Agreements: Politics, Law and Economics, v. 8, n. 2, p. 143-159.

THIERRY, M.; SALOMON, M.; VAN NUNEN, J.; WASSENHOVE, L. N. V. (1995) Strategic Issues in Product Recovery Management. California Management Review. v. 37, n. 2, p. 114-135.

THOMAS, M. T. (2007) Alang ship-breaking yard. Asian Case Research Journal. v. 11, n. 2, p. 327-346.

UNITED NATIONS CONFERENCE ON TRADE AND DEVELOPMENT. (2012) Review of Maritime Transport. United Nations Publication, Geneva.15.

UNITED NATIONS ENVIRONMENT PROGRAMME. (1999) Basel Declaration on Environmentally Sound Management. United Nations Publication, Basel. 2-5. 